УДК 373.3/.5.016:159.922.72]:811.161.2

DOI 10.31494/2412-9208-2019-1-3-105-112

\title{
THE DEVELOPMENT OF EMOTIONAL INTELLIGENCE AS AN IMPORTANT COMPONENT OF LANGUAGE TEACHING IN GENERAL SECONDARY EDUCATION INSTITUTIONS
}

$$
\begin{array}{r}
\text { РОЗВИТОК ЕМОЦІЙНОГО ІНТЕЛЕКТУ } \\
\text { ЯК ВАЖЛИВИЙ КОМПОНЕНТ МЕТОДИКИ НАВЧАННЯ МОВИ } \\
\text { В ЗАКЛАДАХ ЗАГАЛЬНОЇ СЕРЕДНЬОЇ ОСВІТИ }
\end{array}
$$

\author{
Natalia DYKA, \\ $\mathrm{PhD}$ (Pedagogy), Associate \\ Professor \\ Наталія ДИКА, \\ кандидат педагогічних наук, доцент \\ https://orcid.org/0000-0003-1385-5027 \\ n.dyka@kubg.edu.ua \\ Oleksandra GLAZOVA, \\ Олександра ГЛАЗОВА, \\ PhD (Pedagogy), Associate \\ кандидат педагогічних наук, доцент \\ Professor, \\ https://orcid.org/0000-0002-0554-9858 \\ o.glazova@kubg.edu.ua \\ Institute of In-Service Training \\ Borys Grinchenko Kyiv University \\ 22 a P. Tychyny Ave, \\ 02152 Kyiv, Ukraine \\ Інститут післядипломної \\ педагогічної освіти \\ Київський університет \\ імені Бориса Грінченка \\ $\triangle$ пр. П. Тичини, 22 а, 02152 Київ, \\ Україна
}

Original manuscript received: October 10, 2019

ABSTRACT

Revised manuscript accepted: December 17, 2019

The article highlights the peculiarities of the development of emotional intelligence of secondary education students. The relevance of the chosen topic is substantiated and the scientific pedagogical, psychological, linguistic-educational sources are analyzed. Theoretical approaches to understanding the structure of emotional intelligence are generalized, the most common views on emotional intelligence are identified. It presents its structure, which distinguishes five components with short characteristics (self-awareness, self-regulation, motivation, empathy, communication skills). It is noted that, within the Ukrainian language school curricula, teachers traditionally use exercises aimed at developing the emotional sphere of students, but in the light of current scientific research, this part of the educational process requires systematization and ordering. The structure of emotional intelligence is correlated with its functions. The stages of the development of emotional intelligence of secondary education students are given. Samples of multilevel exercises for the effective formation of emotional intelligence of students at the Ukrainian lessons are offered. Emphasis is made on the necessity of constant replenishing of the vocabulary of students with words- names of emotions and feelings in order to interpret their essence. It is emphasized that the enrichment of the active vocabulary by the names of feelings and emotionally colored words will contribute to the improvement of emotional competence. Performing the suggested exercises and tasks during which the students will analyze and ICV 2018: 77.58 
Серія: Педагогічні науки. - Вип.3. - Бердянськ : БДПУ, 2019. - 453 с.

express their own feelings will ensure the development of empathy. Therefore, success in communication and ultimately the formation of emotional intelligence affect the development of the linguistic personality of the student. The development of emotional competence will help to balance the mind and feelings of the individual, will deter from performing actions under the influence of emotions, will prevent manipulation from the side of other persons.

Keywords: emotional intelligence, emotional competence, emotional literacy, general secondary education, linguistics, the methodology of teaching Ukrainian.

Вступ. Численні дослідження вчених доводять, що високі показники емоційного інтелекту позитивно позначаються на процесі міжособистісної взаємодії та соціалізації особистості, її фрізичному та психічному блогополуччі, $\epsilon$ передумовою розвитку моральності, детермінантою емоційного самоконтролю, значною мірою, забезпечуючи успішність життєдіяльності людини загалом. Терміни емоційна компетентність та емоційна грамотність набувають все ширшої актуалізації.

Безумовно, проблеми розвитку емоційного інтелекту дітей та шкільної молоді в освітньому процесі залишаються відкритими. На нашу думку, актуальним видається дослідження розвитку емоційного інтелекту в дитячому та юнацькому віці в процесі вивчення мови.

Мета статті - розкрити зміст поняття емоційний інтелект, ознайомити вчителів зі складниками емоційного інтелекту, методикою його розвитку на уроках української мови.

Методи та методики дослідження. Для розв'язання поставлених завдань використано комплекс методів дослідження:

теоретичні: вивчення та аналіз лінгвістичної, психологопедагогічної і навчально-методичної літератури з проблеми дослідження, методичний аналіз поданого матеріалу, теоретичне осмислення передового педагогічного досліду вчителів-словесників;

емпіричні: спостереження, бесіда 3 учителями й учнями, анкетування 3 метою вивчення стану роботи 3 розвитку емоційного інтелекту, аналіз уроків, письмових робіт та усних відповідей учнів.

Проблема розвитку емоційного інтелекту (EQ) перебуває в центрі уваги передусім психологів і педагогів. Серед зарубіжних дослідників слід назвати Г. Гарднера, Д. Гоулмана, Д. Карузо, Дж. Майєра, П. Саловея та ін. Питання емоційного інтелекту досліджували українські науковці Т. Березовська, С. Дерев'янко, О. Милославська, А. Костюк, Е. Носенко, А. Подорожня, О. Савченко, Г. Свідерська, О. Філатова та ін. У межах шкільних програм з української мови словесники традиційно реалізують вправи, спрямовані на розвиток емоційної сфери учнів, проте 3 урахуванням актуальних наукових досліджень цей аспект освітнього процесу потребує систематизації та упорядкування.

Теоретичні підходи до розуміння структури емоційного інтелекту різняться, проте аналіз концепцій EQ свідчить про те, що більшість дослідників співвідносять його структурні компоненти з певною групою здібностей - когнітивних, емоційних, особистісних, соціальних.

Результати та дискусії. Термін емоційний інтелект запроваджений у 1995 році американцем Деніелем Ґоулманом, його 
концепція "виросла" з поняття соціального інтелекту (дослідження психологів Е. Торндайка, Д. Гілфорда, Г. Айзенка), який визначають як спроможність адаптуватися до життєвих реалій на основі мислительної діяльності. Дехто з науковців стверджує, що емоційний інтелект $є$ підструктурою соціального інтелекту.

Д. Ґоулман (2018, с. 97-114) виділяє чотири головні складники EQ: самосвідомість (self-awareness), самоконтроль (self-management), емпатія (empathy) і навички взаємин, тобто комунікабельність (relationship skills). Визначення та ознаки кожного зі складників подано в таблиці 1.

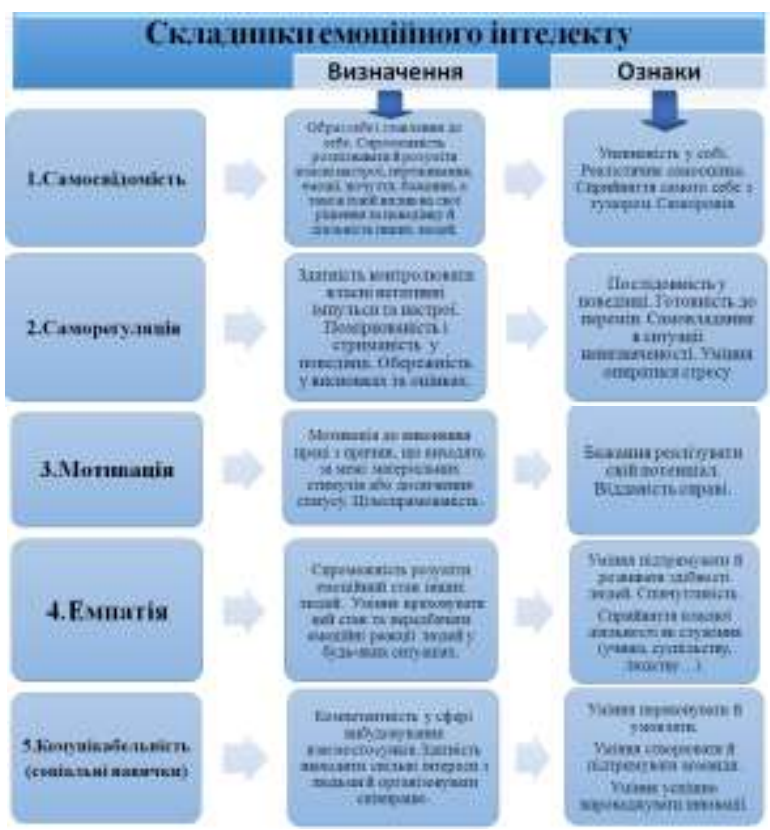

Таблиця 1

Для словесників важливо, що кінцевим результатом вимірів емоційного інтелекту вважають саме комунікабельність, тобто комунікативну компетентність, яку визначають як сукупність знань і вмінь учасників інтеракції спілкування в різноманітних умовах (ситуаціях), набір комунікативних стратегій разом із оволодінням комунікативними правилами (Бацевич, 2004). Словесник працює й над формуванням в учнів комунікативної грамотності, тобто сукупності комунікативних знань, умінь і навичок, які забезпечують можливість ефективного спілкування в усній і писемній формах (Бацевич, 2004, с. 328).

Згідно 3 концепцією Г. Гарднера (1994), у структурі емоційного інтелекту необхідно розглядати внутрішньоособистісний (спрямований на власні емоції) та міжособистісний (спрямований на емоції інших людей) компоненти. Перший характеризується такими складниками, як самосвідомість, рефрлексія, самооцінка, самоконтроль, мотивація досягнень. 
Другий компонент включає емпатію, толерантність, комунікабельність, конгруентність, діалогічність.

Організація Об'єднаних Націй з питань освіти, науки і культури (ЮНЕСКО) спільно з Дитячим фрондом Організації Об'єднаних Націй (ЮНІСЕФ) та у співпраці 3 іншими міжнародними і національними організаціями запропонували концептуальну модель для розроблення освітніх програм. Модель має чотири виміри навчання: когнітивний: учитися знати (пізнавати, вчитися); інструментальний: учитися застосовувати знання (діяти); особистий: учитися бути (жити в злагоді з собою); соціальний - для активного громадянства (жити в мирі та злагоді з іншими).

Відповідно до кожного з вимірів визначено домінантні життєві навички, які ЮНІСЕФ визначає як психосоціальні такі компетентності: когнітивні, особистісні, емоційні та соціальні. Такі навички $є$ універсальними здатностями, необхідними кожній людині для застосування в усіх сфрерах їі життя, незалежно від професійної спеціалізації.

А. Костюк (2014) виділяє в структурі емоційного інтелекту когнітивні, емоційні, адаптивні та соціальні здібності. Взаємозв'язок здібностей із функціями EQ відображено в таблиці 2.

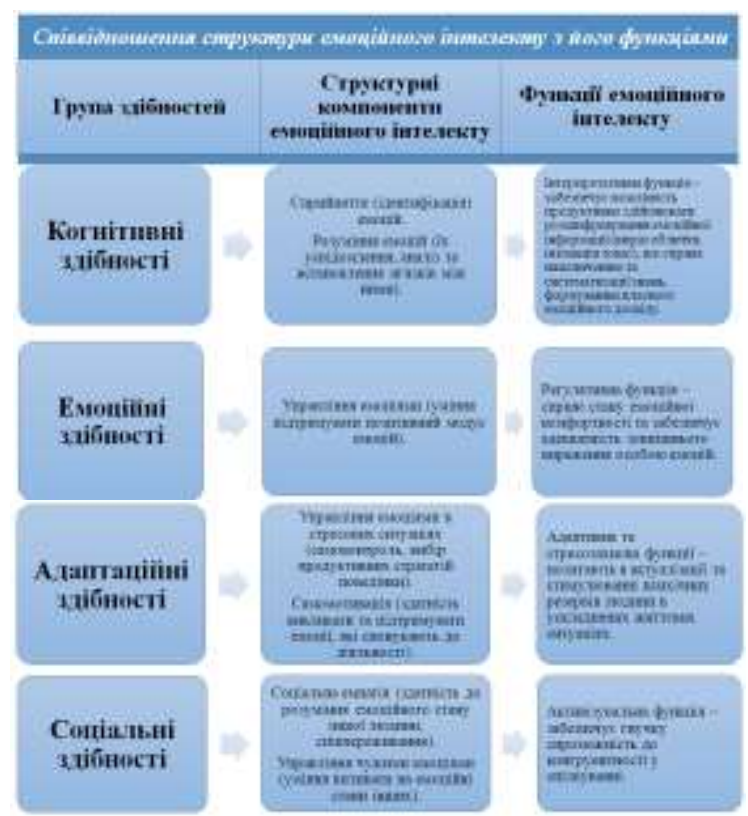

Таблиця 2

Термін емпатія сучасний тлумачний психологічний словник пояснює як "розуміння емоційного стану, проникнення 6 переживання іншої людини" (Шапар, 2007, с. 129). Як особливі форми емпатії виділяють: співпереживання (переживання тих же емоційних станів, що й інша людина) та співчуття (переживання 
власних емоційних станів у зв'язку з почуттями іншої особи).

Розвиток емоційного інтелекту на уроках мови доцільно здійснювати за такими віковими етапами:

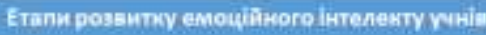

Таблиця 3

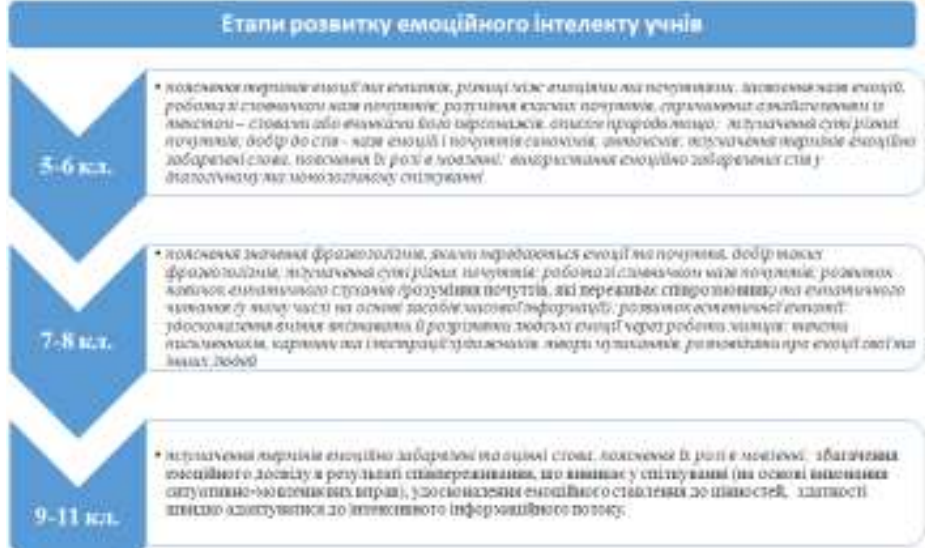

Пропонуємо зразки різнорівневих вправ, які сприяють розвитку емоційного інтелекту.

7-8 класи

- Після перегляду вистави в Театрі юного глядача двоє восьмикласників обмінюються враженнями. Одному 3 них сподобалася п'єса, але він не зовсім задоволений грою виконавців головних ролей. Другому сподобалося все, крім музичного супроводу, який видається йому несучасним. Складіть і розіграйте діалог між учнями. Для вираження почуттів використайте деякі 3 поданих фрразеологізмів (на вибір).

Хвилювання: серце завмерло; узяло за душу; кидало то в жар, то в холод; клубок став у горлі.

Захоплення: miшuть душу(око); бути без пам»яті від когось (чогось); поринути з головою (у щось).

Байдужість: ні холодно ні жарко; і вухом не вести; як з гуски вода; як горохом об стіну.

- Прочитайте. Визначте слова іншомовного походження, лексичне значення кожного з'ясуйте за тлумачним словничком.

Урбанізація - бурхливий розвиток міст і міського способу життя змінює взаємостосунки між людьми. У великому місті людина упродовж одного дня вступає в швидкоплинне й часто мимовільне спілкування 3 кількома сотнями людей.

Такі контакти викликають утому від калейдоскопа облич. Зростає потреба у співчутті, співпереживанні (За Є. Головахою, Н. Паніною). 
Серія: Педагогічні науки. - Вип.3. - Бердянськ : БДПУ, 2019. - 453 с.

* Великі міста часто називають кам'яними джунглями. Як ви розумієте таку назву? Які почуття вона у вас викликає?

* Витлумачте суть названих у тексті почуттів. Скористайтеся словничком назв почуттів.

* Назвіть почуття, які може відчувати людина, опинившись у чужому їй великому місті. Живучи у великому місті постійно? Чи прагне вона спілкування з природою? 3 якої причини?

\section{0-11 класи}

- Прочитайте. Визначте в тексті неологізми, витлумачте лексичне значення кожного. Звіртеся 3 тлумачним словничком.

Cофрія - розроблений компанією Hanson Robotics людиноподібний робот, гіноїд, популярний через свою подібність до людини, спроможність виражати мімікою понад 60 емоцій і давати влучні відповіді на запитання.

Західні експерти не погоджуються з тим, що робота можна назвати штучним інтелектом. Робот Софія - лише чат-бот, який розпізнає запитання за ключовими словами і добирає відповідь із визначеної бази.

Визнання можливості докорінних змін у житті людини (особливо осіб з інвалідністю) за допомогою передових технологій називають трансгуманізмом (від лат. trans - крізь, через, за; humanitas - людяність; humanus - людяний; homo - людина).

* 3 якою метою науковці намагаються наділити людиноподібних роботів хоча б видимістю емоційності? У відповіді вживайте вжиті в тексті неологізми.

* Чи вдасться, на вашу думку, створити "емоційного" робота? Чому?

* Як ви ставитеся до ідеї створення штучного інтелекту? У чому він зможе і в чому не зможе зрівнятися з людиною? Відповідь обгрунтуйте.

Висновки. Зміст, форми і методи навчання мови можуть і мають підпорядковуватися традиційній формулі “Пізнай себе”, проте в дещо осучасненій інтерпретації - "Пізнай себе, свої емоції та почуття й навчися керувати собою”. Необхідно безперервно поповнювати словниковий запас учнів словами-назвами емоцій і почуттів, витлумачувати їх суть. Збагачення активного словника назвами почуттів, емоційно забарвлених слів, виконання вправ і завдань, виконуючи які, учні аналізуватимуть і висловлюватимуть власні почуття, що сприятиме удосконаленню емоційної компетентності, розвитку емпатії, а відтак успішності у спілкуванні, і врешті-решт формуванню емоційного інтелекту, розвиток якого допомагатиме встановленню рівноваги між розумом і почуттями особистості, утримуватиме від виконання дій під впливом емоцій, запобігатиме маніпулюванню з боку інших осіб.

\section{Література}

1. Бацевич Ф.С. Основи комунікативної лінгвістики: підручник. К.: Видавничий центр «Академія», 2004. 342 с.

2. Березюк Г. Емоційний інтелект як детермінанта внутрішньої свободи особистості. Психологічні студії Львівського університету, 2002. С. 20-23.

3. Ґоулман Деніел. Емоційний інтелект. К: Видавництво "Віват", 2018. 512 с. 
4. Дика Н.М. і Глазова О.П. Нова парадигма післядипломної педагогічної освіти: реалізація компетентнісного підходу. Неперервна професійна освіта: теорія і практика (Серія: Педагогічні науки). Випуск № 3-4 (56-57), 2018. С. 14-20. DOI: $10.28925 / 1609-8595.2018(3-4) 1420$

5. Костюк А.В. Емоційний інтелект та шляхи його розвитку. Науковий вісник Херсонського державного університету. Серія: Психологічні науки, 2014. Вип. 2(1). С. 85-89.

6. Українська мова Програма для загальноосвітніх навчальних закладів: 5-9 класи. Дивослово, 2017. № 7-8. URL:http://mon.gov.ua/activity/education/zagalnaserednya/navchalniprogrami-5-9-klas-2017.html (дата звернення: 06.10.2019).

7. Українська мова Програма для загальноосвітніх навчальних закладів: 10, 11 класи. Дивослово, 2018. № 7-8. URL:https://mon.gov.ua/ua/osvita/zagalnaserednya-osvita/navchalni-programi/navchalni-programi-dlya-10-11-klasiv (дата звернення: 05.10.2019).

8. Шапар В.Б. Сучасний тлумачний психологічний словник. Х.: Прапор, 2007. $640 \mathrm{c}$.

9. Bates E., Devescovi A., D’Amico S. Processing complex sentences: A cross-linguistic study. Language and Cognitive Processes. 1999. № 14 (1). P. 69-123. DOI: 10.1080/016909699386383.

10. Gardner H. Frames of Mind. London: Fontana Press, 1994. 466 p.

\section{References}

1. Bacevych F.S. (2004). Osnovy komunikatyvnoji linghvistyky: pidruchnyk [Fundamentals of Communicative Linguistics: A Textbook.]. K.: Vydavnychyj centr «Akademija», 342 (ukr).

2. Berezjuk Gh. (2002). Emocijnyj intelekt jak determinanta vnutrishnjoji svobody osobystosti [Emotional intelligence as a determinant of inner personality freedom]. Psykhologhichni studiji Ljvivsjkogho universytetu, 20-23. (ukr).

3. Goulman Deniel. (2018). Emocijnyj intelekt [Emotional intelligence]. K: Vydavnyctvo "Vivat", 512 (ukr).

4. Dyka N.M. i Ghlazova O.P. (2018). Nova paradyghma pisljadyplomnoji pedaghoghichnoji osvity: realizacija kompetentnisnogho pidkhodu [A new paradigm of postgraduate pedagogical education: realization of the competent approach]. Neperervna profesijna osvita: teorija i praktyka (Serija: Pedaghoghichni nauky). Vypusk 3-4 (56-57), 14-20. DOI: 10.28925/1609-8595.2018(3-4)1420 (ukr).

5. Kostjuk A.V. (2014). Emocijnyj intelekt ta shljakhy jogho rozvytku [Emotional intelligence and ways of its development]. Naukovyj visnyk Khersonsjkogho derzhavnogho universytetu. Serija: Psykhologhichni nauky, Vyp. 2 (1), 85-89 (ukr).

6. Ukrajinsjka mova. Proghrama dlja zaghaljnoosvitnikh navchaljnykh zakladiv: 5-9 klasy [Ukrainian language. Program for general educational institutions 5-9 classes]. (2017). Dyvoslovo, 7-8. Retrieved from http://mon.gov.ua/activity/education/zagalnaserednya/navchalniprogrami-5-9-klas-2017.html (ukr).

7. Ukrajinsjka mova. Proghrama dlja zaghaljnoosvitnikh navchaljnykh zakladiv: 10, 11 klasy [Ukrainian language. Program for general educational institutions 10, 11 classes]. (2018). Dyvoslovo, 7-8. Retrieved from https://mon.gov.ua/ua/osvita/zagalnaserednya-osvita/navchalni-programi/navchalni-programi-dlya-10-11-klasiv (ukr).

8. Shapar V.B. (2007). Suchasnyj tlumachnyj psykhologhichnyj slovnyk [Modern interpretive psychological dictionary]. Kh.: Prapor, 640 (ukr).

9. Bates E., Devescovi A., D`Amico S. (1999). Processing complex sentences: A cross-linguistic study. Language and Cognitive Processes, 14 (1), 69-123. DOI: 10.1080/016909699386383 (eng).

10. Gardner H. (1994). Frames of Mind. London: Fontana Press, 466 (eng). 


\section{АНОТАЦІЯ}

У статті висвітлено особливості розвитку емоційного інтелекту в учнів закладів загальної середньої освіти. Обгрунтовано актуальність обраної теми та проаналізовано наукові педагогічні, психологічні, лінгводидактичні джерела. Узагальнено теоретичні підходи до розуміння структури емоційного інтелекту, визначено найбільш поширені погляди на емоційний інтелект, подано його структуру. Співвіднесено структуру емоційного інтелекту з його функціями. Наведено етапи розвитку емоційного інтелекту в учнів закладів загальної середньої освіти. Запропоновано зразки різнорівневих вправ.

Ключові слова: емочійний інтелект, емочійна компетентність, емоційна грамотність, загальна середня освіта, лінгводидактика, методика навчання української мови. 